\title{
LINGUAGEM EM (DIS)CURSO (UNISUL), V. 4: ESPECIAL, 2004.
}

\author{
Resenhado por: Tatiana R. N. Dias
}

A revista Linguagem em (Dis)curso, produzida pela Unisul, é indexada a vários periódicos internacionais. Possui como prioridade a apresentação de trabalhos relacionados ao texto e ao discurso. No volume 4, edição especial, há uma apresentação do tema Análise do Discurso, observando que se relaciona a uma das abordagens propostas pela revista.

$\mathrm{O}$ volume é dividido em três partes: a primeira, denominada artigos de pesquisa, apresenta textos de teóricos da análise do discurso, como Carmen Rosa Caldas-Coulthard e Theo van Leeuwen, que discutem a questão do semiótico como aspecto significativo para análises textuais e discursivas. Destaca-se que o texto dos autores foi publicado originalmente no livro Gender identity and discourse analysis, de Litosseliti e Sunderland (2002), sendo resultado do projeto "Brinquedos como Comunicação". O artigo apresenta uma análise semiótica de brinquedos, identificando como influem, de maneira direta, nos/as atores/as sociais, fazendo-nos refletir sobre o papel da semiose nas construções sociais, como o gênero.

Além do referido artigo, outros dois textos referentes ao tema gênero social são apresentados. O primeiro, de Débora de Carvalho Figueiredo, versa sobre o discurso legal e a violência sexual, e o outro, de Viviane M. Herbele, tem como proposta a análise de revistas para mulheres no século XXI. Outro tema de importância é abordado por Célia Magalhães que apresenta o discurso sobre raças em reportagens brasileiras. Todos os artigos fazem lembrar o proposto por Fairclough (2003: 2), ao considerar que a Análise de Discurso Crítica "é baseada no pressuposto de que a linguagem é uma parte irredutível da vida social, dialeticamente interconectada a outros elementos da vida social, de forma que a análise e a pesquisa social sempre têm de considerar a linguagem". A sugestão de Fairclough enfatiza a relação dialética entre discurso e sociedade.

Observando qual seria o papel do/a analista do discurso e debatendo sobre possíveis ferramentas para a análise discursiva, a revista apresenta, em sua segunda parte, denominada ensaios, a posição de quatro pesquisadores.

No primeiro ensaio, denominado Teoria crítica do discurso e texto, Izabel Magalhães mostra a relação entre Análise de Discurso Textualmente Orientada e Lingüística Sistêmico-Funcional, contribuindo para uma Análise de Discurso Crítica e fazendo-nos questionar sobre o que significa pro- 
duzir uma análise verdadeiramente crítica. No segundo ensaio, José Luiz Meurer apresenta um novo conceito de intercontextualidade, trazendo conceitos de Giddens (1984) e da Lingüística Sistêmico-Funcional (Halliday, 1994), e ampliando a análise do contexto. O terceiro, de Malcolm Coulthard, considera a complexidade de lingüistas atuarem como peritos legais, muitas vezes sendo avaliadas suas considerações como de menor importância. Por meio de casos de júri, nota que, em sua maioria, "lingüistas forenses têm tido um notável sucesso", indicando a importância de uma Análise do Discurso que contribua para entender questões sociais também em contextos legais. O quarto ensaio, de Peter White, apresenta uma reflexão e um possível método para o estudo da valoração, que se originou na Lingüística Sistêmico-Funcional, propondo uma nova abordagem metodológica para lidar com questões de avaliação.

Em sua parte final, denominada retrospectiva, são apresentados dois textos cuja leitura é muito recomendada a analistas críticos, o primeiro, de Roger Fowler, sobre o surgimento da Lingüística Crítica, suas posições e contribuições, que tiveram como resultado a Análise de Discurso Crítica.

O segundo ensaio, de Ruth Wodak, apresenta conceitos e reflexões relacionados à Análise de Discurso Crítica, comentando sobre o percurso histórico desenvolvido pela teoria. Também propicia questionamentos sobre quais os papéis que devem ser adotados por analistas e quais as abordagens metodológicas que poderiam contribuir para o desenvolvimento da área.

A revista cumpre aquilo a que se propõe, pois, com a escolha de autores com posições diferenciadas - como Ruth Wodak que se destaca em Análise de Discurso Crítica por uma visão historicista; Carmen Rosa Caldas-Coulthard e Theo van Leeuwen que propõem uma análise semiótica; Roger Fowler, um dos fundadores da Lingüística Crítica; Izabel Magalhães, precursora da Análise de Discurso Crítica no Brasil - podemos obter uma maior abrangência de conceitos e perceber como essas diversas posições podem relacionar-se, levando-nos à reflexão e a uma nova visão da Análise do Discurso, com o diferencial de ser uma revista nacional, com textos em língua portuguesa.

\section{Referências Bibliográficas}

Fairclough, N. Analysing discourse. Textual analysis for social research. Londres, Nova York, 2003.

Giddens, A. The constitution of society. Cambridge: Polity Press, 1984. 
Halliday, M. A. K. An introduction to functional grammar. 2 ed. Londres: Edward Arnold, 1994.

Litosseliti, L.; Sunderland, J. (Orgs.) Gender identity and discourse analysis. Amsterdã: John Benjamins, 2002. 